\title{
Evaluating the Residual Nitrite Concentrations of Bacon in the United Kingdom
}

\author{
William Crowe, Christopher T Elliott $\mathbb{D}$ and Brian D Green *
}

Institute of Global Food Security, School of Biological Sciences, Queens University Belfast, Belfast BT9 5DL, UK; w.crowe@qub.ac.uk (W.C.); chris.elliott@qub.ac.uk (C.T.E.)

* Correspondence: b.green@qub.ac.uk; Tel.: +44-(0)28-90976541

Received: 9 June 2020; Accepted: 9 July 2020; Published: 11 July 2020

check for updates

\begin{abstract}
The preservative sodium nitrite is added to processed meat with the intention of preventing the growth of Clostridium botulinum, but this also influences product flavour and colour. The World Health Organisation has declared nitrites to be 'probably carcinogenic'. Use is permitted by the European Union but its addition is limited to $100 \mathrm{mg} / \mathrm{kg}$ in all processed meat, except bacon, which is limited to $175 \mathrm{mg} / \mathrm{kg}$. At present, there is no independent peer-reviewed literature assessing the residual nitrite levels in bacon in the United Kingdom. Furthermore, this is the largest study of residual nitrite concentrations in bacon that has ever been conducted. A total of 89 different commercially available bacon samples were collected, and analysed using flow injection analysis to determine their residual nitrite content. The mean residual nitrite concentration for all bacon samples was $10.80 \mathrm{mg} / \mathrm{kg}$. Residual nitrite levels did not differ between smoked and unsmoked bacon. Middle cut bacon $(26.00 \mathrm{mg} / \mathrm{kg})$ had significantly higher residual nitrite concentrations than back bacon $(8.87 \mathrm{mg} / \mathrm{kg} ; p=0.027)$, and medallion bacon $(4.47 \mathrm{mg} / \mathrm{kg} ; p=0.008)$. This study shows that there is large variation in the mean residual nitrite levels of bacon sold in the UK and all the reported values are within current regulatory limits. Despite this, it appears that many manufacturers could decrease the amount that they are currently using in their products.
\end{abstract}

Keywords: nitrite; bacon; processed meat

\section{Introduction}

Nitrite salts are curing agents added to processed meat with the aim of enhancing shelf life, flavour, and colour. Commonly used forms of nitrite salts include sodium nitrite and potassium nitrite. Nitrite salts are effective antimicrobial agents that elicit their effects by decreasing water potential, delaying oxidative rancidity, and subsequently preventing the growth of bacteria. Manufacturers typically use nitrite salts to prevent the growth of Clostridium botulinum [1]. Clostridium botulinum is a rod-shaped anaerobic bacteria that produces botulinum toxin, which is responsible for causing the neuroparalytic condition botulism. In severe cases, botulism can lead to respiratory failure and death. Botulism is rare in Europe-the incidence rate has ranged between 85 and 124 annually in the past 10 years [2]. Nitrite also influences the colour of meat. Oxymyoglobin is responsible for the red/pink colour of meat. The loss of an electron from oxymyoglobin leads to the formation of metmyoglobin, subsequently turning the meat brown. The meat colour change is temporary, given that many things can influence this oxidation reaction, such as the presence of bacteria, aging and cooking. Nitric oxide (NO) arising from sodium nitrite combines with myoglobin in the presence of deoxymyoglobin to form the heat-stable NO myoglobin. The NO acts as a substitute for oxygen, contributing an increasing pink colour to the meat [3], which is a desirable trait for consumers [4]. Unreacted nitrite within meat is known as residual nitrite, and this portion is readily measurable. Some manufacturers substitute nitrite for vegetable extracts that contain 
nitrate to cure meats, which ultimately results in the generation of nitrite [5], and these products are marketed as natural bacon. Uncured meats refer to meat where no nitrite or equivalent has been added. Consumers indicate a preference for bacon with nitrite added, and score it higher for colour acceptability, flavour, and texture [6]. Concerns have been raised with regard to the safety of natural bacon, with studies showing higher levels of bacterial growth present on their surface [7].

Processed meats have been classified as a group 1 carcinogen by the International Agency for Research on Cancer (IARC) [8], and they define processed meat as any meat that has been altered through salting, curing, smoking or other processes, with the aim of preserving or improving the flavour of the meat. It is reported that the daily consumption of $50 \mathrm{~g}$ of processed meat, which is approximately two rashers of bacon, increases the risk of colorectal cancer (CRC) by $18 \%$ [8]. It is unclear what constituent(s) present in processed meat are responsible for the cancer-promoting effects. Leading candidates include nitrites, polycyclic aromatic hydrocarbons (PAHs), haloacetic acids (HAAs), haem iron, and saturated fats. Nitrites have emerged as the foremost contender due to their ability to generate N-nitroso compounds (NOCs), some of which are known to be carcinogenic [9]. Nitrite is classed as a group 2A carcinogen and described as probably carcinogenic [10]. A European Parliament and Council Directive has restricted the addition of sodium nitrite in processed meat to $150 \mathrm{mg} / \mathrm{kg}$, and the residual amount must be below $100 \mathrm{mg} / \mathrm{kg}$. In cured bacon, the residual amount must be below $175 \mathrm{mg} / \mathrm{kg}$ (EC 95/2/EC) [11]. The joint Food and Agriculture Organisation of the United Nations/World Health Organisation (FAO/WHO) expert committee on food additives (JECFA) has agreed an acceptable daily intake (ADI) of nitrite to be $0.07 \mathrm{mg} / \mathrm{kg}$ bodyweight [1]. This dosage was calculated whilst considering carcinogenicity and the development of methaemoglobin [1]. The ADI is the quantity of a compound that can be consumed every day over a lifetime without conferring any health risk.

According to EU Regulation No. 1169/2011, all products with nitrite added must list this on the ingredient list, either explicitly as sodium/potassium nitrite or stating the E number (E250/E249). However, the quantity of nitrite does not need to be specified on the label. At present, there is no independent scientific literature determining the residual nitrite concentrations found in bacon sold in the UK. The aim of this investigation was to measure the mean residual nitrite concentration of bacon samples available in the UK, and the secondary aim was to compare the residual nitrite concentrations of bacon of different types and cuts.

\section{Materials and Methods}

\subsection{Samples}

A total of 89 bacon samples were purchased from the shelves of 4 large UK supermarket chains (Asda, Sainsbury's, Tesco and Lidl). Samples were all purchased on the same day and stored in refrigeration at $4^{\circ} \mathrm{C}$ until shipment, which occurred on the same day of purchase. Samples were removed from original packaging and placed in transparent plastic bags, anonymised and coded. Samples were shipped in Styrofoam containers lined with ice packs to Eurofins scientific (Wolverhampton, England). Samples were non-discriminatorily purchased based on their availability, which represents consumer purchasing trends. Commercially available bacon samples included back $(n=52)$, streaky $(n=13)$, middle $(n=6)$, medallions $(n=15)$, and diced $(n=3)$.

\subsection{Determination of Residual Nitrite Levels}

The proximal analysis values self-reported by manufacturers on product labels were recorded in a database and included in statistical analysis (Table 1). Five grams of each bacon sample was weighed to the nearest $0.1 \mathrm{mg}$ and triturated for $5 \mathrm{~min}$ in individual mortars. Distilled water was added at a volume of $40 \mathrm{~mL}$ and the mixture was added to a water bath at a temperature of $80^{\circ} \mathrm{C}$ for $120 \mathrm{~min}$. The liquid was passed through a $0.45 \mathrm{~m}$ Whatman syringe filter twice before analysis. All samples were analysed for nitrite concentrations using the flow injection analysis (FIA) method [12]. A nitrite standard at a concentration of $1000 \mu \mathrm{g} / \mathrm{mL}^{-1}$ was prepared by adding $150 \mathrm{mg}$ of sodium 
nitrite (Merck, Darmstadt, Germany) to $1 \mathrm{~mL}$ chloroform, 1 pellet of sodium hydroxide and $\mathrm{dH} 2 \mathrm{o}$ at a total volume of $100 \mathrm{~mL}$. The samples with unknown nitrite concentrations were injected into the FIA through the reaction manifold. Ammonium chloride was injected at a flow rate of $1.2 \mathrm{~mL} / \mathrm{min}$, and reacted with the sample in the reaction coil, which was $100 \mathrm{~cm}$. Nitrite present in the sample reacts with a colouring reagent that consists of sulphanilamide and $\mathrm{N}$-(1-naphthyl) ethylenediamine dihydrochloride, and this reaction forms diazonium salt, which causes a colour change that can be measured spectrophotometrically at $540 \mathrm{~nm}$. The colour change was proportional to the concentration of nitrite, relative to the standard. The concentration of sodium nitrite was recorded as $\mathrm{mg} / \mathrm{kg}$, and the lower limit of reporting (LLOR) for sodium nitrite was $1 \mathrm{mg} / \mathrm{kg}$.

Table 1. Mean (SD) proximal analysis concentrations of bacon samples $(n=89)$ stratified by processing status.

\begin{tabular}{ccccc}
\hline & All Bacon & Smoked & Unsmoked & $p$ \\
\hline Residual nitrite $\mathrm{mg} / \mathrm{kg}$ & $10.80(13.50)$ & $10.44(14.08)$ & $11.03(13.27)$ & 0.691 \\
Energy Kcal/100 g & $224.68(57.15)$ & $229.83(54.97)$ & $221.63(54.97)$ & 0.556 \\
Fat g/100 g & $14.57(6.20)$ & $15.42(6.69)$ & $14.06(5.91)$ & 0.370 \\
Saturated fat g/100 g & $5.64(2.58)$ & $5.91(2.83)$ & $5.49(2.43)$ & 0.508 \\
Carbohydrate g/100 g & $0.46(0.43)$ & $0.53(0.51)$ & $0.44(0.40)$ & 0.146 \\
Sugars g/100 g & $0.35(0.31)$ & $0.39(0.33)$ & $0.33(0.29)$ & 0.342 \\
Protein g/100 g & $21.39(6.47)$ & $20.70(6.10)$ & $21.67(6.66)$ & 0.631 \\
Salt g/100 g & $3.12(0.78)$ & $3.04(0.66)$ & $3.28(0.84)$ & 0.202 \\
\hline
\end{tabular}

An alpha value of $<0.05$ indicates significant difference, as determined by an independent $\mathrm{T}$ test. The difference is between smoked and unsmoked bacon. g, grams; Kcal, kilocalories; SD, standard deviation.

\subsection{Data Analysis}

Statistical analysis was conducted using the IBM statistics package for social science (SPSS) version 25 (New York, NY, United States). Data was tested for normality using the Kolmogorov-Smirnov test. As carbohydrates, sugar, protein and salt were not normally distributed, they were logarithmically transformed. All other variables were normally distributed. The arithmetic mean $( \pm \mathrm{SD})$ on their natural scale was used to present data. Differences in mean residual nitrite concentrations between smoked and unsmoked samples were determined using an independent $t$ test, as were differences in manufacturer reported nutritional content. A one-way analysis of variance (ANOVA) test was used to assess differences in mean residual nitrite concentrations between different cuts of bacon-back, middle, streaky and medallion. An alpha value of $<0.05$ indicated significance, and least significant difference (LSD) was used to determine which groups were significantly different from each other. Pearson's correlation coefficient was used to measure the linear correlation between residual nitrite, energy, fat, and protein content.

\section{Results}

Table 1 shows the descriptive statistics of $n=89$ bacon samples collected from UK supermarkets. The mean $( \pm \mathrm{SD})$ residual nitrite concentration of bacon samples collected from supermarkets was $10.80 \mathrm{mg} / \mathrm{kg}( \pm 13.50)$, the limit of detection was $1 \mathrm{mg} / \mathrm{kg}$, and 15 samples that were below this were imputed as $1 \mathrm{mg} / \mathrm{kg}$. The range of residual nitrite concentrations for the 89 samples was $1-56 \mathrm{mg} / \mathrm{kg}$. There was no difference in residual nitrite concentrations between smoked and unsmoked bacon $(p=0.691)$. As shown in Table 2, middle bacon had the highest residual nitrite concentration, and this was significantly higher than for the medallion $(p=0.008)$ and back $(p=0.027)$ bacon. Streaky bacon had the next highest residual nitrite concentration, and this was significantly higher than for the medallion $(p=0.013)$ and back $(p=0.005)$ bacon. Streaky bacon had the highest energy $(268.33 \mathrm{kcal})$, and this was significantly higher than for back $(p=0.027)$, medallion $(p \leq 0.001)$, and diced $(p=0.030)$ bacon. Streaky bacon also had the highest fat levels $(21.45 \mathrm{~g})$, and this was significantly higher than for the back $(p \leq 0.001)$, medallion $(p \leq 0.001)$, and diced $(p=0.005)$ bacon. Streaky bacon also had 
the highest saturated fat content $(8.68 \mathrm{~g} / 100 \mathrm{~g})$, and this was significantly higher than for the back $(p \leq 0.001)$, medallion $(p \leq 0.001)$, and diced $(p=0.009)$ bacon. Streaky bacon had the lowest protein content $(18.00 \mathrm{~g} / 100 \mathrm{~g})$.

Table 2. Mean (SD) proximal analysis concentrations of bacon samples $(n=89)$ stratified by cut.

\begin{tabular}{|c|c|c|c|c|c|}
\hline & Back $(n=52)$ & Streaky $(n=13)$ & Middle $(n=6)$ & Medallions $(n=15)$ & Diced $(n=3)$ \\
\hline Residual nitrite $\mathrm{mg} / \mathrm{kg}$ & $8.87(9.65) \mathbb{I}, ¥$ & $19.87(21.72) \ddagger$ ‡ & $\begin{array}{c}26.00(20.33) \\
\ddagger, \|, \psi\end{array}$ & $4.47(3.41) \mathbb{I}, ¥$ & $6.37(6.61) \mathbb{I}, ¥$ \\
\hline Energy Kcal/100 g & 229.56 (46.19) $\mathbb{I}, \|$ & $268.33(60.04) \ddagger, \|, \psi$ & $260.00(56.67) \|$ & $149.90(44.21) \ddagger, \mathbb{I}, ¥$ & $197.67(18.48) \mathbb{I}$ \\
\hline Fat $\mathrm{g} / 100 \mathrm{~g}$ & 15.07 (4.58) II,\| & $21.45(5.78) \ddagger, \|, \psi$ & $18.26(3.67) \|$ & $4.27(1.56) \ddagger, \mathbb{I}, \|, \psi$ & $13.13(0.75) \mathbb{I}, \|$ \\
\hline Saturated fat $\mathrm{g} / 100 \mathrm{~g}$ & $5.70(2.00) \mathbb{I}, \|$ & 8.68 (2.48) $\ddagger, \|, \psi$ & $7.44(0.97) \|$ & $1.76(0.69) \ddagger, \Psi, ¥, \psi$ & $5.33(0.12) \mathbb{I}, \|$ \\
\hline Carbohydrate $\mathrm{g} / 100 \mathrm{~g}$ & $0.54(0.45)$ & $0.24(0.34)$ & $0.63(2.87)$ & $0.23(0.32)$ & $0.50(0.71)$ \\
\hline Sugars $\mathrm{g} / 100 \mathrm{~g}$ & $0.39(0.32)$ & $0.22(0.22)$ & $0.38(0.25)$ & $0.25(0.25)$ & $0.50(0.71)$ \\
\hline Protein $\mathrm{g} / 100 \mathrm{~g}$ & $21.76(6.70)$ & $18.00(5.68)$ & $21.33(7.22)$ & $23.56(6.37)$ & $19.27(2.37)$ \\
\hline Salt g/100 g & $3.10(0.70)$ & $3.10(0.56)$ & $3.30(0.94)$ & $3.71(1.16)$ & $3.60(1.21)$ \\
\hline
\end{tabular}

An alpha value of $<0.05$ indicates significant difference, as determined by a one-way ANOVA comparing cuts of bacon. g, grams; Kcal, kilocalories; SD, standard deviation. Groups significantly different from back are indicated by $\ddagger$, groups significantly different from streaky are indicated by $\mathbb{I}$, groups significantly different from middle are indicated by $¥$, groups significantly different from medallion are indicated by $\|$, and groups significantly different from diced are indicated by $\psi$.

Conversely, medallions had the lowest residual nitrite $(4.47 \mathrm{mg} / \mathrm{kg})$, energy $(149.90 \mathrm{kcal})$, fat $(4.27 \mathrm{~g})$, saturated fat $(1.76 \mathrm{~g} / 100 \mathrm{~g})$, and the highest protein $(23.56 \mathrm{~g} / 100 \mathrm{~g})$. Despite residual nitrite concentrations differing amongst the cuts, there was no difference in total salt concentrations between the four cuts. As shown in Figure 1, there was a positive correlation between residual nitrite and energy $(r=0.260$, $p=0.022)$, fat $(r=0.263, p=0.021)$, and saturated fat $(r=0.284, p=0.012)$.
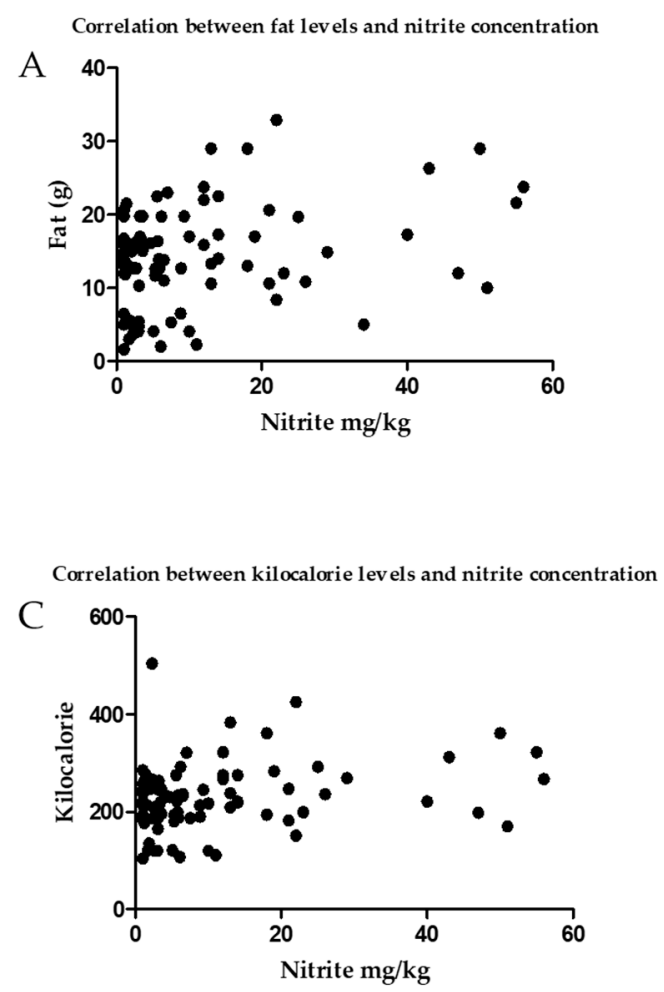
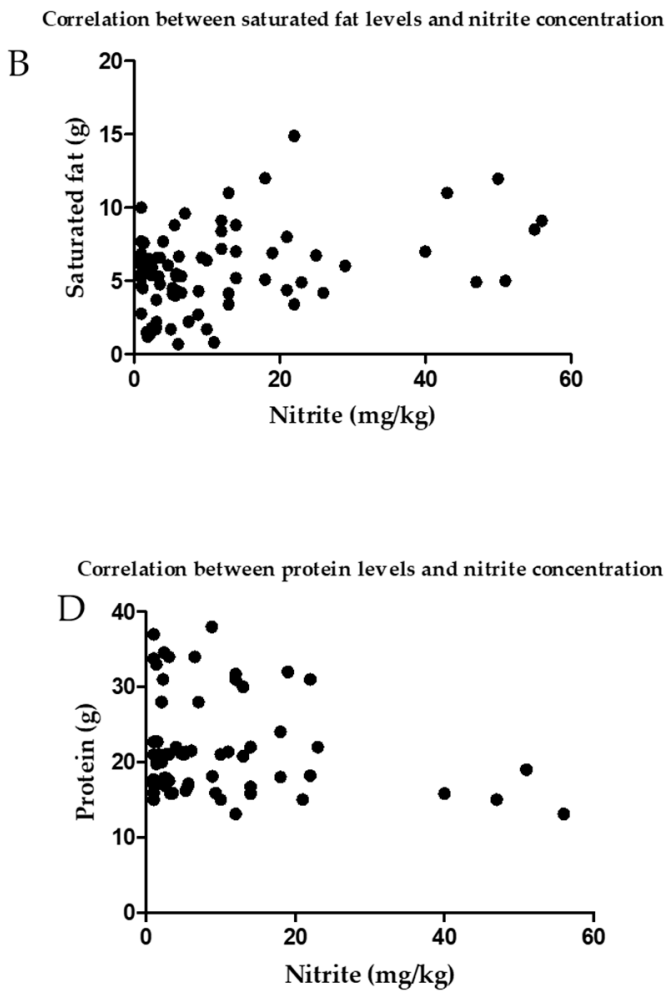

Figure 1. Correlation between residual nitrite concentration and (A) fat levels, (B) saturated fat levels, (C) kilocalorie levels, and (D) protein in bacon samples.

\section{Discussion}

We report the mean $( \pm \mathrm{SD})$ residual nitrite concentration in bacon sold in UK supermarkets to be $10.80( \pm 13.50) \mathrm{mg} / \mathrm{kg}$. Middle bacon had the highest mean residual nitrite level $(26.00 \pm 20.33 \mathrm{mg} / \mathrm{kg})$, 
which was almost 3 times higher than back bacon, and more than 5 times higher than bacon medallions. Streaky bacon was next highest for residual nitrite levels $(19.98 \mathrm{mg} / \mathrm{kg})$, which was 4.5 times higher than bacon medallions. Streaky bacon had the highest energy, fat and saturated fat levels, and the lowest protein levels. Medallion bacon had the lowest energy, fat and saturated fat levels, and the highest protein levels. There was a correlation between the levels of residual nitrite and the levels of fat in all samples. There was no difference in residual nitrite concentrations between smoked and unsmoked bacon.

This was the first study in the UK to survey residual nitrite concentrations in bacon samples, and it was the most extensive worldwide, having the largest sample size. The results were similar to research surveying cured meats available in China and the USA. Yuan et al. [13] reported a mean residual nitrite concentration of ham as $16.1 \mathrm{mg} / \mathrm{kg}$ and sausage as $12.5 \mathrm{mg} / \mathrm{kg}$. Their study collected 48 uncooked cured meat products, and the number of ham, sausage or other cured meats was not stated. A small study of nine uncooked bacon samples in the USA reported that the mean residual nitrite concentration was $10.43 \mathrm{mg} / \mathrm{kg}$, which, despite the difference in sample size, is close to the value reported here [7]. Three further studies conducted in the United States reported mean residual nitrite values lower than the current study. A study of 20 uncooked, brine cured bacon samples collected from 5 cities in America found that the mean residual nitrite concentration was $6.8 \mathrm{mg} / \mathrm{kg}$ [14]. In a similarly designed USA based study, the mean residual nitrite concentration of bacon samples was $7.31 \mathrm{mg} / \mathrm{kg}$ [15]. Cassens (1997) [16] sampled three bacon samples and reported a mean residual nitrite concentration of $6.67 \mathrm{mg} / \mathrm{kg}$. Conversely, studies conducted in Brazil, South Korea, and Australia reported levels over 2 times higher than that of this study. Twenty-one samples of Brazilian processed meat were analysed for residual nitrite concentrations and the mean value was reported as $22.4 \mathrm{mg} / \mathrm{kg}$, and when stratifying the samples by type of processed meat, ham had an average value of $47.25 \mathrm{mg} / \mathrm{kg}$ and dry cured ham had a value of $9.4 \mathrm{mg} / \mathrm{kg}$ [17]. An in vitro study of bacterial growth on media treated with sodium chloride reported that a sample of bacon from South Korea had a residual nitrite concentration of $26 \mathrm{mg} / \mathrm{kg}$, although the method of analysis was unclear [18]. Food Standards Australia and New Zealand (FSANZ) analysed 15 bacon samples and reported a mean of $26.6 \mathrm{mg} / \mathrm{kg}$ and a range of $12-45 \mathrm{mg} / \mathrm{kg}$ [19]. None of the aforementioned studies reported the cuts of bacon used. The most commonly consumed cut in the USA is streaky bacon, whilst the most commonly consumed in the UK is back bacon [20]. Our study highlights that streaky bacon in the UK tends to have higher residual nitrite concentrations than back bacon, and it may, therefore, be expected for residual nitrite levels in bacon from USA studies to be higher than is reported. The lower residual nitrite concentrations reported in the USA might be explained by the increased use of reductants in American-manufactured processed meat. Bacon produced in the USA must contain either ascorbate or sodium erythorbate, and these increase the reduction of nitrite to $\mathrm{NO}$, making less nitrite available for quantification-this also subsequently makes less nitrite available for conversation to potentially carcinogenic nitrosamines. From the moment nitrite is added to a product, the amount of residual nitrite present begins to decline. The concentration of residual nitrite in sausages, has been observed to be between 5 and $19 \%$ of the original concentration at the use by date [21]. Neither ourselves or any of the previous studies can confidentially report the time between the addition of sodium nitrite and laboratory measurement of residual nitrite.

We report that middle bacon has the highest residual nitrite concentration and medallion has the lowest. There was a positive correlation between residual nitrite concentrations and fat levels, saturated fat, and energy. The higher residual nitrite levels in middle and streaky bacon are either due to more sodium nitrite being added during curing, or less incorporation of nitrite into the meat.

All samples in this study were well below the maximum permitted limit of $175 \mathrm{mg} / \mathrm{kg}$ specified by EFSA (2003) [11]. Concerns have been raised regarding the negative health effects that habitual consumption of nitrite may have. Nitrite has been shown to form NOCs in certain conditions, nitrosyl heme acts as a nitrosating agent for amines in this process, leading to potentially carcinogenic compounds [22]. A growing body of evidence has implicated nitrites in the development of CRC [23]. 
We are unable to definitively measure the total amount of nitrite added to bacon samples. When sodium nitrite is added to meat, it is reduced to $\mathrm{NO}$ and can no longer be detected. Furthermore, the rate of conversion is dependent on many factors, including $\mathrm{pH}$, ratio of nitrite to myoglobin, temperature, water content, and the presence of reductants [24]. We, therefore, are unable to accurately calculate the exposure to nitrite adducts, which may enhance the risk of DNA damage.

Due to commercial availability (and consumer purchasing habits), this study had substantially more back bacon samples than any other cut. Future research could increase the quantity of middle, medallion, streaky, and diced bacon to allow for more accurate comparisons. Our study lacked other forms of nitrite-containing processed meat. Further research could include frankfurter, salami, ham, and pepperoni. Gaining an accurate estimation of the nitrite concentrations in all processed meat will allow for a better approximation of population exposure. The existing literature suggests that young children are at the greatest risk of exceeding the ADI for nitrite [25-27], even in Denmark where the maximum residual nitrite concentration allowed in bacon is $60 \mathrm{mg} / \mathrm{kg}$. Further research on population exposure is needed to definitively draw conclusions from our results.

\section{Conclusions}

This study demonstrates that the mean residual nitrite concentration of bacon sold in the UK is similar to that sold in the US, and we also showed that the mean residual nitrite concentration is substantially lower than the allowable limit. Even samples with the highest measured concentrations are still considerably lower than this limit. It is not clear whether some manufacturers are adding sodium nitrite considerably below the allowable limit, or whether the sodium nitrite added is reacting with other constituents and is no longer measurable. Future research should investigate the kinetics of sodium nitrite reactions occurring after addition to meat. Given the current WHO position that sodium nitrite addition to processed meat is 'probably carcinogenic', it seems logical to add concentrations high enough to prevent spoilage but also sufficiently low enough to minimise health risk. Further research should be conducted to more precisely define an appropriate sodium nitrite concentration range.

Author Contributions: B.D.G. and W.C. conceived the study. W.C. obtained, repacked and coded samples. W.C. shipped the samples to Eurofins and conducted statistical analysis. W.C. wrote the manuscript, which was edited by C.T.E. and B.D.G. All authors have read and agreed to the published version of the manuscript.

Funding: This study formed part of a larger project that investigated links between processed meat consumption and CRC, which are in part supported by Agri-Food QUEST, a membership-based, industry-led innovation centre for agri-food business in Northern Ireland. Agri-Food QUEST is supported by funding from Invest Northern Ireland.

Acknowledgments: We wish to acknowledge two undergraduate students that contributed to the sample selection and handling-Natalie Winder and Zoë Burns.

Conflicts of Interest: A currently-held Agri-Food Quest project is partially supported by commercial funding from: Finnebrogue Artisan, Karro Food group, and Cranswick. Industrial partners were not involved in the design or writing of the manuscript, the analysis/interpretation of the data, or the decision to publish.

\section{References}

1. Mortensen, A. Re-evaluation of potassium nitrite (E 249) and sodium nitrite (E 250) as food additives. EFSA J. 2017, 15, e04786. [PubMed]

2. Surveillance Atlas; European Centre for Disease Prevention and Control: Solna, Sweden, 2018.

3. Shiva, S.; Huang, Z.; Grubina, R.; Sun, J.; Ringwood, L.A.; MacArthur, P.H.; Xu, X.; Murphy, E.; Darley-Usmar, V.; Gladwin, M.T. Deoxymyoglobin Is a Nitrite Reductase That Generates Nitric Oxide and Regulates Mitochondrial Respiration. Circ. Res. 2007, 100, 654-661. [CrossRef] [PubMed]

4. Farouk, M. Improving the Quality of Restructured and Convenience Meat Products; Woodhead Publishing: Cambridge, UK, 2011.

5. Sebranek, J.G.; Bacus, J.N. Cured meat products without direct addition of nitrate or nitrite: What are the issues? Meat Sci. 2007, 77, 136-147. [CrossRef] [PubMed] 
6. Sindelar, J.; Cordray, J.C.; Olson, D.; Sebranek, J.; Love, J. Investigating Quality Attributes and Consumer Acceptance of Uncured, No-Nitrate/Nitrite-Added Commercial Hams, Bacons, and Frankfurters. J. Food Sci. 2007, 72, S551-S559. [CrossRef] [PubMed]

7. Jackson, A.L.; Sullivan, G.A.; Kulchaiyawat, C.; Sebranek, J.G.; Dickson, J.S. Survival and Growth of Clostridium perfringens in Commercial No-Nitrate-or-Nitrite-Added (Natural and Organic) Frankfurters, Hams, and Bacon. J. Food Prot. 2011, 74, 410-416. [CrossRef]

8. IARC Working Group. Monographs on the Evaluation of Carcinogenic Risks to Humans; The Lancet Oncology: Lyon, France, 2018.

9. IARC. Ingested nitrate and nitrite, and cyanobacterial peptide toxins. In Evaluation of Carcinogenic Risks to Humans; IARC Monographs: Lyon, France, 2010.

10. Grosse, Y. Carcinogenicity of nitrate, nitrite, and cyanobacterial peptide toxins. Lancet Oncol. 2006, 7, 628-629. [CrossRef]

11. European Food Safety Authority (EFSA). Opinion of the Scientific Panel on Biological Hazards on the effects of Nitrites/Nitrates on the Microbiological Safety of Meat Products. EFSA J. 2003, 14, 1-31.

12. Penteado, J.C.; Angnes, L.; Masini, J.C.; Oliveira, P.C.C. FIA-Spectrophotometric Method for Determination of Nitrite in Meat Products: An Experiment Exploring Color Reduction of an Azo-Compound. J. Chem. Educ. 2005, 82, 1074-1078. [CrossRef]

13. Yuan, Y. Survey of nitrite content in foods from north-east China. Food Addit. Contam. Part B Surveill. 2010, 3 , 39-44. [CrossRef]

14. De González, M.T.N. Survey of Residual Nitrite and Nitrate in Conventional and Organic/Natural/Uncured/ Indirectly Cured Meats Available at Retail in the United States. J. Agric. Food Chem. 2012, 60, 3981-3990. [CrossRef]

15. Keeton, J.T.; Osburn, W.N.; Hardin, M.D.; Bryan, N.S. A national survey of the nitrite/nitrate concentrations in cured meat products and non meat foods available at retail. J. Agric. Food Chem. 2009, 60, 3981-3990.

16. Cassens, R.G. Composition and safety of cured meats in the USA. Food Chem. 1997, 59, 561-566. [CrossRef]

17. Oliveira, S.; Lopes, T.; Rangel, A.O.S.S. Spectrophotometric Determination of Nitrite and Nitrate in Cured Meat by Sequential Injection Analysis. J. Food Sci. 2006, 69, C690-C695. [CrossRef]

18. Jo, H. Probabilistic Models to Predict the Growth Initiation Time for Pseudomonas spp. in Processed Meats Formulated with $\mathrm{NaCl}$ and $\mathrm{NaNO}$. Food Sci. Anim. Resour. 2014, 34, 736-741. [CrossRef]

19. FSANZ. Survey of Nitrates and Nitrites in Food and Beverages in. Available online: https://www.foodstandards. govt.nz/consumer/additives/nitrate/Documents/Survey $\% 20 \mathrm{of} \% 20$ nitrates $\% 20$ and $\% 20$ nitrites.pdf (accessed on 10 July 2020).

20. Catlett, L. Consumer Demands and Regional Preferences for Meat; Woodhead Publishing: Cambridge, UK, 2011.

21. Merino, L.; Darnerud, P.O.; Toldrá, F.; Ilbäck, N.-G. Time-dependent depletion of nitrite in pork/beef and chicken meat products and its effect on nitrite intake estimation. Food Addit. Contam. Part A Chem. Anal. Control. Expo. Risk Assess. 2016, 33, 186-192. [CrossRef]

22. Kobayashi, J. Effect of diet and gut environment on the gastrointestinal formation of N-nitroso compounds: A review. Nitric Oxide 2018, 73, 66-73. [CrossRef]

23. Crowe, W.; Elliott, C.T.; Green, B.D. A Review of the In Vivo Evidence Investigating the Role of Nitrite Exposure from Processed Meat Consumption in the Development of Colorectal Cancer. Nutrients 2019, 11, 2673. [CrossRef]

24. Yang, F. Effects of reducing reagents and temperature on conversion of nitrite and nitrate to nitric oxide and detection of NO by chemiluminescence. Clin. Chem. 1997, 43, 657-662. [CrossRef]

25. Leth, T.; Fagt, S.; Nielsen, S.; Andersen, R. Nitrite and nitrate content in meat products and estimated intake in Denmark from 1998 to 2006. Food Addit. Contam. Part A Chem. Anal. Control. Expo. Risk Assess. 2008, 25, 1237-1245. [CrossRef]

26. Reinik, M. Nitrites, nitrates and N-nitrosoamines in Estonian cured meat products: Intake by Estonian children and adolescents. Food Addit. Contam. 2005, 22, 1098-1105. [CrossRef] [PubMed]

27. Larsson, K.; Darnerud, P.O.; Ilbäck, N.-G.; Merino, L. Estimated dietary intake of nitrite and nitrate in Swedish children. Food Addit. Contam. Part A Chem. Anal. Control. Expo. Risk Assess. 2011, 28, 659-666. [CrossRef] [PubMed]

(C) 2020 by the authors. Licensee MDPI, Basel, Switzerland. This article is an open access article distributed under the terms and conditions of the Creative Commons Attribution (CC BY) license (http://creativecommons.org/licenses/by/4.0/). 